\author{
RESENSI BUKU \\ Judul Buku : Memahami Hukum dan Kode Etika Komunikasi \\ Penulis : Alip Yoga Kunandar, Indah Suryawati \\ Penerbit : Galuh Patria, Yogyakarta \\ Tahun : 2019 \\ Tebal : 198 halaman
}

\title{
Masalah-Masalah Hukum dan Kode Etik Komunikasi di Indonesia
}

\author{
Meylisa Yuliastuti Sahan \\ Universitas Budi Luhur \\ Email : sahanmeylisa1596@gmail.com \\ Jl. Ciledug Raya, Petukangan Utara, Jakarta Selatan, 12260 \\ Telp: 021-585 3753 Fax: 021-585 3752
}

Submitted: 08 October 2019 Revised: 13 October 2019 Accepted: 15 October 2019

Kita semua sepakat bahwa komunikasi merupakan proses pertukaran pesan antara dua orang yang disebut komunikator dan komunikan. Pesan ini banyak bentuknya, begitupula dengan komunikator dan komunikan. Namun, proses komunikasi tidak hanya berhenti sampai pada definisi ini. Hal lain yang masuk dalam proses komunikasi adalah feedback atau timbal balik atau respon yang diberikan lawan bicara. Berbicara soal komunikasi, proses ini juga tidak hanya mengenai pesan yang dibawa namun dampak dari pesan tersebut, sehingga diperlukan sebuah sistem yang mengatur, sebuah pakem atau batasan sehingga informasi yang dibawa tidak bias atau malah akhirnya merugikan salah satu pihak.

Sistem ini akhirnya disebut sebagai Hukum dan Etika yang secara jelas membuat batasan dalam berkomunikasi, baik lisan maupun tertulis, kritik maupun saran semua sudah ada koridor dan batasannya. Selain untuk membatasi dan mengatur pola komunikasi yang baik, hukum dan etika dibutuhkan untuk menjaga komunikasi berjalan dengan baik serta tidak menimbulkan kerugian bagi siapapun yang terlibat dalam proses komunikasi ini.

Ini adalah salah satu alasan atau pokok pikiran yang ingin disampaikan oleh penulis dalam buku ini. Bagaimana saat ini, terpaan informasi semakin banyak serta media pendukung penyebaran informasi secara luas makin berkembang. Setiap orang merasa memiliki kewajiban untuk mengomentari sesuatu sampai dengan menjadi hakim pemutus sebuah masalah. Kebebasan berpendapat berkolaborasi dengan akses internet dan media sosial yang semakin besar membuat hal ini sepertinya tidak dapat dihindarkan. Selain media sosial, media mainstream seperti televisi, radio, majalah bahkan film juga berlomba-lomba untuk menyampaikan pendapat terkait dengan sebuah kejadian. Sebuah masalah nasional akan menjadi topik pembicaraan yang 
hangat para penyiar radio ketika siaran atau sebuah kejadian viral akan langsung diproduksi sebagai film, sebut saja kejadian thread twitter yang menggemparkan Indonesia yaitu "KKN Desa Penari" yang tinggal menunggu waktu untuk bertengger di bioksop.

Buku ini mencoba untuk menjelaskan aspek hukum dan etika dalam berkomunikasi secara keseluruhan di Indonesia, terutama dalam bidang pers dan jurnalisme, penyiaran, perfilman, periklanan, komunikasi siber hingga etika dan hukum dalam berbagai profesi komunikasi. Diawali dengan penjelasan mengenai perbedaan antara hukum dan etika dalam komunikasi, lalu sejarah perkembangan pers dan jurnaslime serta penyiaran, perfilman, periklanan dan komunikasi siber. Setiap akhir bab juga akan dilengkapi dengan contoh pelanggaran atau kasus mengenai hukum dan etika komunikasi. Untuk menampilakan secara garis besar isi buku ini, berikut adalah tabel berisi bab dan subbab dalam buku ini, sebagai berikut :

Tabel 1. Gambaran Umum Isi Buku

\begin{tabular}{|c|c|c|}
\hline No. & Judul Bab & Sub-bab \\
\hline 1. & Bab 1 : Hukum dan Etika & $\begin{array}{l}\text { A. Pendahuluan } \\
\text { B. Pengertian Hukum dan Etika } \\
\text { C. Sistem Hukum di Indonesia }\end{array}$ \\
\hline 2. & Bab 2 : Pers dan Jurnalisme & $\begin{array}{l}\text { A. Pendahuluan } \\
\text { B. Pengertian Pers dan Jurnalisme } \\
\text { C. Sejarah Pers di Indonesia } \\
\text { D. Hukum Pers di Indonesia } \\
\text { E. Etika Jurnalistik } \\
\text { F. Masalah-masalah dalam Pers dan } \\
\quad \text { Jurnalisme }\end{array}$ \\
\hline 3. & Bab 3 : Penyiaran & $\begin{array}{l}\text { A. Pendahuluan } \\
\text { B. Pengertian Penyiaran } \\
\text { C. Sejarah Penyiaran di Indonesia } \\
\text { D. Regulasi Penyiaran di Indonesia } \\
\text { E. Pedoman dan Standart Penyiaran } \\
\text { F. Masalah-masalah dalam Penyiaran }\end{array}$ \\
\hline 4. & Bab 4 : Perfilman & $\begin{array}{l}\text { A. Pendahuluan } \\
\text { B. Sejarah Perfilman di Indonesia } \\
\text { C. Regulasi Pefilman di Indonesia } \\
\text { D. Pedoman dan Kriteria Sensor } \\
\text { E. Masalah-masalah dalam perfilman }\end{array}$ \\
\hline 5. & Bab 5 : Periklanan & $\begin{array}{l}\text { A. Pendahuluan } \\
\text { B. Sejarah Periklanan di Indonesia } \\
\text { C. Hukum Periklanan } \\
\text { D. Etika Periklanan di Indonesia } \\
\text { E. Masalah-masalah dalam Periklanan }\end{array}$ \\
\hline 6. & Bab 6 : Public Relations & $\begin{array}{l}\text { A. Pendahuluan } \\
\text { B. Sejarah dan Pengertian PR } \\
\text { C. Hukum dan Etika PR } \\
\text { D. Masalah-masalah Public Relations }\end{array}$ \\
\hline 7. & Bab 7 : Komunikasi Siber & $\begin{array}{l}\text { A. Pendahuluan } \\
\text { B. Pengertian Komunikasi Siber } \\
\text { C. Hukum \& Etika Komunikasi Siber } \\
\text { D. Masalah-masalah Komunikasi } \\
\quad \text { Siber }\end{array}$ \\
\hline
\end{tabular}


Sumber : Buku Memahami Hukum \& Etika Komunikasi

Berdasarkan penjelasan singkat yang dijelaskan dan tabel diatas, maka dapat dilihat dengan jelas bahwa buku ini akan memfokuskan pembahasannya mengenai hukum dan kode etik komunikasi serta penerapannya dalam masing-masing bidang. Contoh kasus yang dimuat dalam sub bab masalah adalah kejadian yang terjadi di Indonesia.

\section{Hukum dan Etika}

Hukum secara umum dapat dijelaskan sebagai sebuah aturan resmi yang memiliki konsekuensi jelas karena sifatnya yang mengikat dan wajib. Vant Kan (dalam Kunandar, Suryawati: 2019:11) mendefinisikan hukum adalah serumpun peraturan-peraturan yang bersifat memaksa yang diadakan untuk mengatur dan melindungi kepentingan orang di dalam masyarakat. Berdasarkan pengertian ini dapat disimpulkan bahwa hukum adalah sebuah aturan yang diproduksi oleh masyarakat yang tujuannya juga untuk mengatur masyarakat.

Menurut Aristoteles (dalam Kunandar, Suryawati : 2019:11) etika memiliki dua pengertian yaitu terminus technicus yaitu etika sebagai ilmu pengetahuan dan manner and custom yakni etika yang berhubungan dengan tata cara dan adat kebiasaan yang melekat dalam diri manusia. Buku ini memfokuskan isinya pada hubungan manusia dan etikanya yang dipengaruhi oleh tata cara dan kebiasaan yang dilakukan, meliputi lingkungan yang membentuknya serta adat istiadat yang dianut sejak kecil yang merupakan pola dalam keluarga.
Hukum dan Kode Etik merupakan dua hal yang tidak dapat dipisahkan jika merujuk pada dua pengertian diatas, hal ini tentu saja harus berjalan beriringan untuk menghasilkan komunikasi yang saling menguntungkan baik bagi komunikator maupun komunikan. Perbandingan paling mendasar antara Hukum dan Etika bahwa hukum terbentuk atas kepentingan masyarakat dan juga negara, sementara etika lahir dari norma-norma yang dibuat dalam sebuah sistem masyarakat. Penulis buku ini juga menjelaskan bahwa hukum ditujukan kepada manusia sebagai makhluk sosial, sedangkan etika ditujukan kepada manusia sebagai individu. Lalu, hukum bersifat memaksa namun dapat diubah sesuai dengan zaman, sementara etika tidak bersifat memaksa namun tidak dapat diubah (Kunandar, Suryawati: 2019:12).

Hukum dan Etika di Indonesia sudah lahir sejak zaman penjajahan. Selain itu hukum dan etika yang berlaku di Indonesia juga lahir dari munculnya kerajaan-kerajaan zaman Hindu-Budha dan Islam di Indonesia. Sampai saat ini masih banyak hukum adat dan etika yang dibawa turun temurun sebagai pedoman kehidupan berbangsa dan bernegara masyarakat kita, nilai-nilai ini selalu dipegang teguh. Adapun jenis dan peraturan hierarki Peraturan Perundangundangan terdiri atas (Kunandar, Suryawati: 2019:16) :

1. Undang-Undang Dasar Negara Republik Indonesia Tahun 1945

2. Ketetapan Majelis Permusyawaratan Rakyat 
3. Undang-Undang/Peraturan Pemerintah Pengganti UndangUndang

4. Peraturan Pemerintah

5. Peraturan Presiden

6. Peraturan Daerah Provinsi; dan

7. Peraturan Daerah Kabupaten/Kota

\section{Komunikasi dan Media Massa}

Komunikasi massa melibatkan dua aktor utama yaitu komunikator dan komunikan, namun kedua aktor ini tidak hanya menjurus kepada satu orang saja atau suatu kelompok tertentu. Menurut Alexis Tan ( dalam Nurudin: 2007:20) komunikator dalam komunikasi massa adalah organisasi sosial yang mampu memproduksi pesan dan mengirimkannya secara serempak kepada khalayak, misalnya koran, surat kabar, televisi, radio dan film. Media massa dapat muncul karena adanya kerjasama antara banyak pihak.

Media massa yang terus mengalami perubahan membawa dampak yang besar dalam proses penyebaran informasi. Jika dahulu kegiatan komunikasi mengandalkan komunikasi tatap muka dan komunikasi kelompok sebagai pola komunikasi yang diandalkan maka adanya perkembangan teknologi komunikasi yang kian pesat mendukung proses komunikasi tersebut. Teknlogi komunikasi ini akhirnya melahirkan sebuah alat komunikasi baru yang media sosial yang dapat diakses kapanpun dan dimanapun oleh siapapun selama ada jangkauan atau koneksi internet.
Media sosial sebagai sarana untuk mendapatkan berbagai informasi dan hiburan. Saat ini hampir semua media massa dapat dijangkau dengan mudah, misalnya surat kabar yang dulunya berbentuk cetakan sekarang dapat dinikmati secara digital. Jika dulu informasi penting atau breaking news baru dapat terbit di koran edisi berikutnya, maka dengan kecepatan internet kejadian ini akan langsung muncul sepersekian detik. Informasi yang datang menghampiri seseorang datang dari berbagai jenis media yang digunakan orang tersebut. Ingin bertatap muka namun terhalang jarak, maka fitur video call membantu untuk menyelesaikan masalah ini. Perubahanperubahan ini membawa manusia menjadi ketergantungan yang besar terhadap media massa. Manusia tidak dapat terhindar dari terpaan informasi yang dihadirkan oleh media massa bahkan sejak bangun tidur sampai malam hari.

Kemudahan ini akhirnya melahirkan sebuah ruang tanpa batas antara masyarakat dan media sebagai penyedia informasi. Hal ini sejalan dengan media massa yang menggunakan media sosial sebagai "jembatan" selalu menyediakan kolom komentar. Siapapun bisa berkomentar, bisa berpendapat, bisa mengadili bahkan membentuk sanksi sosial bagi seseorang hanya lewat “jembatan" ini. Media massa mampu membentuk atau mempengaruhi perilaku manusia.

Tabel 2. Fungsi Komunikasi Massa Alexis S. Tan

\begin{tabular}{|l|l|l|}
\hline No. & \multicolumn{1}{|c|}{$\begin{array}{c}\text { Tujuan Komunikator } \\
\text { (Penjaga Sistem) }\end{array}$} & $\begin{array}{c}\text { Tujuan Komunikan } \\
\text { (Menyesuaikan diri pada sistem: pemuasan } \\
\text { keputusan) }\end{array}$ \\
\hline 1. & Memberi Informasi & $\begin{array}{l}\text { Mempelajari ancaman dan peluang, } \\
\text { memahami lingkungan, menguji kenyataan, }\end{array}$ \\
\hline
\end{tabular}




\begin{tabular}{|c|c|c|}
\hline & & meraih keputusan \\
\hline 2. & Mendidik & $\begin{array}{l}\text { Memperoleh pengetahuan dan } \\
\text { keterampilan yang berguna memfungsikan } \\
\text { dirinya secara efektif dalam } \\
\text { masyarakatnya, mempelajari nilai, tingkah } \\
\text { laku yang cocok agar diterima dalam } \\
\text { masyarakatnya }\end{array}$ \\
\hline 3. & Mempersuasi & $\begin{array}{l}\text { Memberi keputusan, mengadopsi nilai, } \\
\text { tingkah laku dan aturan yang cocok agar } \\
\text { diterima dalam masyarakatnya }\end{array}$ \\
\hline 4. & $\begin{array}{l}\text { Menyenangkan, } \\
\text { kebutuhan komunikan }\end{array}$ & $\begin{array}{l}\text { Menggembirakan, mengendorkan syaraf, } \\
\text { menghibur dan mengalihkan perhatian dari } \\
\text { masalah yang dihadapi }\end{array}$ \\
\hline
\end{tabular}

Sumber : Nurudin: 2007:65

Berdasarkan tabel diatas, dapat disimpulkan bahwa komunikator dan komunikan dalam media massa sejatinya saling membutuhkan. Komunikator adalah penyedia informasi, misalnya sebuah situs berita di internet seharusnya membuat konten-konten yang tidak hanya bertujuan untuk mendapatkan click dari pembaca namun tetap mengedepankan sisi edukasi. Fenomena judul clickbait yang semakin hari sering kita jumpai seharusnya bisa menjadi bukti bahwa rating akan selalu menjadi urusan nomer satu dalam setiap hal. Masyarakat sebagai komunikan yang rendah keinginan untuk membaca akan dengan mudah terpancing berita jenis ini. Akibatnya, berita yang tidak dibaca secara lengkap menghasilkan informasi yang simpang siur dan berujung pada penyebaran hoax. Kita tentu saja tidak bisa menutup mata dari serangkaian peristiwa hoax atau kabar bohong yang tersebar di Indonesia. Memerangi kejadian ini tentu bukan sebuah pekerjaan rumah yang mudah.

Kasus pencemaran nama baik adalah salah satu bukti dari minimnya informasi yang diperoleh seseorang. Tidak sedikit kasus pencemaran nama baik seseorang yang akhirnya berujung di pengadilan dan pelaku harus mendekam di penjara. Baru-baru ini artis Shandy Aulia yang melaporkan salah satu warga net atau netizen karena merasa dirugikan dan menyerang ranah pribadinya. Dikutip dari detikhot.com Shandy Aulia melaporkan netizen yang menyinggung dirinya perihal body shaming. Ujaran yang tidak pantas dan hinaan tersebut membuat Shandy merasa geram. Laporannya kepada pihak berwajib untuk memberikan pelajaran terkait UU ITE (Undang-Undang Informasi dan Transaksi Elektronik).

Kasus Shandy Aulia merupakan salah satu contoh dari jutaan kasus serupa yang terjadi di Indonesia. Lalu apakah begitu susahnya untuk menjaga pola komunikasi dalam hal ini berkomentar di media sosial seseorang? Untuk menjawab kasus serupa maka dibutuhkan Hukum dan Kode Etik Komunikasi sebagai batasan.

Pada bab tujuh yang membahas mengenai komunikasi siber, permasalahan seperti yang dialami oleh Shandy Aulia termasuk dalam masalah yang berkaitan dengan Hukum dan Etika Komunikasi Siber, khususnya pencemaran nama baik dan pelanggaran privasi. Bagian ini dapat membantu menjelaskan bahwa sebenarnya tidak seluruh masyarakat Indonesia paham kegunaan media sosial dan dampak yang bisa diterima akibat dari komentar buruk terhadap seseorang. Berbagai aturan hukum negara Indonesia juga 
memposisikan pencemaran nama baik sebagai salah satu pasalnya. Hal ini sekaligus membuktikan bahwa selain ujaran kebencian, fitnah dan penghinaan, masyarakat Indonesia masih dengan mudah menghasilkan konten-konten berupa komentar yang mencermakan nama seseorang sehingga masih harus diatur dalam undang-undang. Selain itu, hal ini seharusnya berkaitan erat dengan etika seseorang baik dalam komunikasi langsung atau komunikasi siber di dunia maya. Pencemaran nama baik erat hubungannya dengan pelanggaran privasi seseorang. Seperti sudah dijelaskan diatas, ketika media sosial semakin berkembang dan menjadikan tidak adanya batasan antara satu pengguna dengan pengguna yang lain, maka ruang ini menjadi semakin kecil. Batasan privasi di media sosial adalah sebuah hal yang abu-abu, tidak jelas dan tidak pasti. Privasi seharusnya menjadi tanggungjawab masing-masing orang, namun sekali lagi karena tidak ada batasan yang pasti maka bentuk privasi setiap orang akan berbeda-beda. Misalnya saja, demam maternity shot di kalangan artis Indonesia semakin berkembang. Tidak sedikit yang mengabadikan momen ini dalam bentuk foto lengkap dengan baju dan tema yang dibuat. Biasanya yang menjadi bahan pembicaraan bukanlah momen kehamilan namun baju yang digunakan dalam proses foto tersebut, ada yang menganggap terlalu terbuka dan berlebihan, adapula yang mengatakan sahsah saja karena ingin menunjukkan perut yang hamil dan sebagainya. Komentarkomentar ini lah yang tidak dapat diredam sekaligus karena konten yang diproduksi akan selalu ada, pegiat informasi selalu siap sedia untuk mendapatkan berita lengkap dengan judul yang clickbait, masyarakat yang rendah minat baca sehingga mudah terjebak hanya dari judul dan berlaku konsumen yang selalu menantikan berita terbaru sehingga rasanya ini adalah sebuah lingkaran kegiatan yang tidak akan pernah habis. Kasus terbaru mengenai privasi datang dari seorang artis di Cina yang mengunggah gambar foto dirinya (selfi) ke media sosial, seorang fans fanatik dapat mengetahui lokasi tempat pengambilan foto ini hanya dengan pantulan bayangan di bola mata si artis. Luar biasa bukan?

Masih terkait dengan fitnah, pencemaran nama baik dan ujaran kebencian, dikutip dari liputan6.com Oktober 2019 ini seorang Dandim Kolonel Hendi Supendi dicopot setelah 52 hari menjabat sebagai Komandan Kodim di Kota Kendari. Kejadian ini dilatarbelakangi unggahan istrinya yaitu IZN di media sosial terkait penusukan yang dialami Menko-Polhukam Wiranto, dinilai melanggar disiplin militer.

Kasus-kasus seperti ini masih sering terjadi di Indonesia. Media sosial yang kita gunakan untuk membagikan apapun terkadang menjadi tidak terkontrol karena diri kita sendiri. Tanpa disadari, setiap aktivitas kita di media sosial terekam atau tersimpan dengan baik, apalagi facebook yang bersifat terbuka. Semua orang dengan leluasa membaca unggahan kita, memberikan komentar bahkan dengan mudahnya membagikannya kepada orang lain. Sifat keterbukaan media sosial ini yang seharusnya dipahami banyak orang, buku ini berusaha untuk menjelaskan bahwa melek internet saja bukan bekal untuk menjadi manusia yang terpelajar, namun melek informasi dan bertanggungjawab dengan semua tulisan 
yang dibuat adalah sebuah kebijakan yang harus dimiliki setiap pengguna.

\section{Hukum dan Kode Etik Komunikasi}

Sebagai inti sari dari buku ini, hukum dan kode etik atau etika merupakan dua hal yang tidak dapat dipisahkan dan tentu akan selalu beriringan. Manusia akan selalu terikat dengan hukum suatu negara yang mengatur warga negaranya, sementara peraturan dalam kehidupan bermasyarakat di lingkungan melahirkan hukum etika.

Selain kasus-kasus diatas, mari kita membahas beberapa kasus yang dapat dikaitkan dengan setiap bab yang ada :

1. Kasus kekerasan terhadap wartawan adalah salah satu masalah yang masih belum dapat diatasi dengan baik di Indonesia. Pada tanggal 24 dan 25 September 2019 lalu ketika terjadi demo yang dilakukan oleh mahasiswa di depan gedung DPR-RI ada banyak wartawan yang ditugaskan untuk meliput berita. Namun belakangan beredar video yang berisi seorang polisi memaksa seorang wartawan untuk menghapus video yang direkam di ponselnya. Video ini menunjukkan beberapa orang yang diduga mahasiswa sedang diamankan oleh aparat keamanan. Walaupun sudah dijelaskan bahwa perekam video ini adalah wartawan namun ia tetap mendapatkan perlakuan yang kurang pantas. Dikutip dari voaindonesia.com tercatat ada sepuluh jurnalis atau wartawan yang menjadi korba kekerasan saat demo mahasiswa. Bentuk kekerasan yang dilakukan berupa pemukulan, intimidasi dan penghapusan video rekaman.

2. Selain mendapatkan banyak hate comment dari warga net, Shandy Aulia juga beberapa bulan yang lalu diundang untuk menjadi salah satu bintang tamu dalam acara Q\&A MetroTv dengan tema Polusi di Ruang Publik menuai banyak kecaman dari warga net. Hal yang menjadi sorotan beberapa warga net adalah ketika salah seorang panelis yaitu sutradara John de Rantau mengomentari gaya berpakaian Shandy lewat fotofotonya di media sosial. Banyak sekali yang tidak setuju dengan pendapat tersebut dan mengatakan bahwa pakaian yang digunakan adalah urusan masing-masing orang. Kompas.com juga memuat sebuah artikel yang berisi tanggapan dua orang pakar terkait kasus ini yaitu Harti Muchlas, Direktur Pengembangan Sumberdaya untuk Penghapusan Kekerasan terhadap Perempuan berpendapat bahwa semua perempuan memiliki otoritas penuh terhadap tubuh dan seksualitasnya, tergantung bagaimana norma yang dianut oleh wanita itu sendiri. Selanjutnya, Sri Kusumo Habsari seorang pakar Studi Gender dan Budaya yang memiliki tanggapan berbeda menyatakan bahwa perbedaan pendapat antara Shandy dan John merupakan sebuah hal yang biasa karena ini disangkutpautkan dengan norma yang berlaku dan adat istidat yang dianut Indonesia. Keduanya merupakan public figure yang 
seharusnya mampu untuk memahami itu. Konsekuensi akan selalu mengikuti siapapun itu ketika dia mulai membuka ruang bagi publik untuk masuk kedalamnya.

3. Seperti yang sudah dijelaskan juga dalam buku ini, salah satu masalah terbesar yang dihadapi oleh hukum dan etika komunikasi perfilman adalah kreativitas versus sensor. September 2019 lalu, Komisi Penyiaran Indonesia (KPI) yang memberikan teguran kepada film kartun Spongebob Squarepants karena dianggap mengandung tindakan kekerasan. Warga net Indonesia bereaksi dan cukup banyak yang mengecam hal ini. KPI dianggap terlalu skeptis sementara di satu sisi membiarkan sinetron Indonesia yang mengandung cerita tidak masuk akal dan juga menampilkan sisi kekerasan tidak juga diproses atau ditarik dari pasaran. Berita yang beredar juga simpang siur. Dilansir dari kompas.com teguran yang dilayangkan oleh KPI bukan untuk memberhentikan film kartun ini, namun memberi teguran hanya untuk beberapa segmen tertentu yang dinilai bermuatan kekerasan dan hal ini tidak sesuai dengan Pedoman Perilaku Penyiaran Standar Progam Siaran (P3SP). Di satu sisi mungkin saja tindakan ini dirasa berlebihan karena "ini hanya film kartun" namun di sisi lain, karena penikmat kartun bukan hanya orang dewasa dan kebanyakan menyasar anak-anak sebagai penonton sudah sepatutnya adegan kekerasan tidak masuk ke dalam sebuah tayangan. Perihal sinetron yang tidak masuk akal juga sebaiknya di proses karena dua jenis tayangan ini dapat juga mempengaruhi pola atau tingkah laku anak-anak.

4. Rius Vernandes dan Elwiyana Monica, pasangan youtuber ini dilaporkan ke polisi oleh pihak Garuda Indonesia karena dituduh telah melakukan pencemaran nama baik perusahaan terkait konten $v$ log yang dimuat di channel youtube Rius. Masalah ini bermula ketika Rius dan Monica membuat video review perjalanannya di pesawat Garuda Indonesia dari Australia ke Indonesia. Ada beberapa hal yang di kritik oleh pasangan ini termasuk pelayanan dan kurangnya fasilitas minuman yang ada dalam pesawat ini sampai dengan menu makanan yang ditulis tangan. Video ini berbuntut panjang sampai dengan dikeluarkannya press release bahwa pihak Garuda Indonesia melarang segala bentuk aktivitas pengambilan gambar dalam bentuk apapun selama di dalam pesawat. Tanggapan pihak Garuda Indonesia ini malah di kritik oleh warga net yang menilai bahwa pihak Garuda Indonesia merupakan perusahaan yang anti kritik. Walaupun setelahnya masalah ini diselesaikan dengan jalur kekeluargaan namun kejadian ini akhirnya dibuat menjadi memes oleh beberapa perusahaan di Indonesia seperti Grab yang membuat press release membebaskan para penumpang 
untuk mengambil gambar dengan driver mereka. Tindakan ini dianggap sebagai sindiran atas kebijakan yang dikeluarkan oleh Garuda Indonesia.

\section{SIMPULAN}

Pembahasan soal masalah yang terkait dengan hukum dan kode etik komunikasi di Indonesia sepertinya tidak akan habis. Setiap hari hampir selalu ada celah pelanggaran ini terjadi. Banyak yang berujung di bui, tidak sedikit juga yang memilih untuk mengakhiri pertikaian dengan jalan damai atau kekeluargaan.

Buku ini mencoba untuk memberikan pemahaman lebih mengenai sejarah dari setiap media komunikasi di Indonesia termasuk bentuk komunikasi apa saja yang masih sering menghasilkan pelanggaran hukum dan kode etik. Berbicara mengenai dua hal ini tentu saja merupakan pekerjaan rumah semua orang.

Buku yang diresensi oleh pembaca ini merupakan tulisan yang muncul dari sebuah ide untuk membuat sebuah buku yang isinya memuat secara lengkap mengenai hukum dan kode etik komunikasi yaitu dalam bidang pers dan jurnalisme, penyiaran, perfilman, periklanan, public relations dan komunikasi siber atau cyber communication.

Sebagai sebuah text book pembaca tidak mengalami banyak kesulitan untuk memahami isi dari tulisan yang ada. Informasi yang ditampilkan sangat ringan namun tetap berisi, contoh-contoh kasus yang muncul di akhir bab merupakan kasus-kasus terbaru yang cukup menggemparkan di Indonesia.

Namun, sayangnya pembaca masih menemukan cukup banyak kesalahan dalam penulisan kata, berupa huruf yang kurang atau lebih, penempatan tanda baca dalam kalimat sampai dengan kata yang tidak diberikan jarak atau spasi. Oleh sebab itu semoga dicetakan buku berikutnya kesalahan teknis yang ada ini akan diperbaiki sehingga semakin meningkatkan kualitas membaca.

Terlepas dari kurang dan lebihnya, sebagai sebuah bentuk karya ilmiah sudah seharusnya hal ini diapresasi. Buku ini sangat layak untuk dikonsumsi sabagai sumber informasi baik dalam penulisan jurnal maupun karya penelitian ilmiah lainnya.

DAFTAR PUSTAKA

Anggaraini, Pingkan. (2019, Maret 06). Shandy Auliad Bakal Bawa Perkara Body Shaming ke Kepolisian. Retrieved October, 2019 from https://m.detik.com/hot/celeb/d4456757/shandy-aulia-bakal-bawaperkara-body-shaming-ke-kepolisian?

Fua, Ahmad Akbar. (2019, Oktober 12). Kronologi Dandim Kendari Dicopot Usai Istri Unggah Komentar Soal Wiranto. Retrieved October, 2019 from https://www.google.com/amps/s/m.liput an6.com/amp/4084450/kronologidandim-kendari-dicopot-usai-istriunggah-komentar-soal-wiranto

Kundandar, Alip Yog, dan Indah Suryawati. 2019. Memahami Hukum dan Etika Komunikasi. Yogyakarta: Galuh Patria.

Madrim, Sasmito. (2019, September 28). 10 Jurnlias Jadi Korban Kekerasan Saat Demo Mahasiswa, Retrieved October, 2019 from https://www.google.com/amp/s/www.vo aindonesia.com/amp/5102661.html

Nurudin. 2007. Pengantar Komunikasi Massa. Jakarta: Raja Grafindo Persada.

Wibawa, Shierine Wangsa. (2019, September 18). John de Rantau Kritik Pakian 
Shandy Auli, Dua Pakar Berkometar.

Retrieved October, 2019 from https://www.google.com/amp/s/amp.ko mpas.com/sains/read/2019/09/18/18473 2223/john-de-rantau-kritik-pakaianshandy-aulia-dua-pakar-berkomentar 